\title{
Determination of the taxonomic affiliation of the native isolate of the pigment-forming bacterium, separated from the Vezelka river of the city of Belgorod
}

Lyakhovchenko N.S., Senchenkov V.Yu., Myagkov D.A., Pribylov D.A., Chepurina A.A., Nikishin I.A., Avakova A.A., Goyanov M.A., Gubina E.D., Taptun V.A., Churikova D.A., Sirotin A.A., Solyanikova I.P.

Federal State Autonomous Educational Institution of Higher Education «Belgorod National Research University», Belgorod, Russia

\section{E-mail: lyakhovchenko@bsu.edu.ru}

Key message. The paper presents the results of a study of an aboriginal isolate of a pigment-forming bacterium isolated from the Vezelka River in the city of Belgorod, which makes it possible to determine its taxonomic affiliation.

Keywords: taxonomic affiliation, aboriginal isolate, pigment-forming bacteria, identification

Microorganisms and their consortia, which are part of biocenoses, are characterized by a variety of ongoing biochemical processes that represent biotechnological potential. Isolation and study of the properties of new microorganisms and their consortia contributes both to deepening fundamental knowledge about the processes occurring in biotopes and their individual cells, and to meeting the practical needs of a biotechnological cluster by constructing new, based on the knowledge gained on existing, metabolic pathways that allow one to obtain products necessary for the person. The aim of the study is to determine the taxonomic affiliation of the native bacterial isolate, followed by a search for its biotechnological potential.

Thus, an indigenous pigment-forming bacterium from the Vezelka River in the city of Belgorod, Belgorod Region, was represented, represented by gram-negative, pigment-forming blue-violet, facultatively anaerobic, catalase-positive, does not form indole bacilli with such characteristic properties as the ability to grow at $4{ }^{\circ} \mathrm{C}$, the manifestation of lecithinase activity, but not $\mathrm{H} 2 \mathrm{~S}$, the presence of cytochrome oxidase, the absence of lipolytic activity and capsule formation. Based on the detected signs, the primary taxonomic affiliation of the selected microorganism to the genus Chromobacterium was determined.

The isolated bacterium was able to exhibit antagonistic properties against phytopathogens such as Alternaria brassicicola F1864 and Aspergillus unguis F-1754, which may include its biotechnological potential as an active agent of plant protection products.

The work was supported by Grant RFBR-China № 20-54-53023.

\section{Определение таксономической принадлежности аборигенного изолята пигментообразующей бактерии, выделенной из реки Везёлка города Белгорода}

Ляховченко Н.С., Сенченков В.Ю., Мягков Д.А., Прибылов Д.А., Чепурина А.А., Никишин И.А., Авакова А.А., Гоянов М.А., Губина Е.Д., Таптун В.А., Чурикова Д.А., Сиротин А.А., Соляникова И.П.

ФГАО ВО «Белгородский государственный национальный исследовательский университет», Белгород, Россия

\author{
Аннотация. В работе представлены результаты исследования аборигенного изолята пигментообразующей \\ бактерии, выделенной из реки Везёлка города Белгорода, позволяющие определить её таксономическую \\ принадлежность.
}

Ключевые слова: таксономическая принадлежность, аборигенный изолят, пигментообразующие бактерии, идентификация

Микроорганизмы и их консорциумы, входящие в состав биоценозов, характеризуются разнообразием протекающих в них биохимических процессов, представляющих биотехнологический потенциал. Выделение и изучение свойств новых микроорганизмов и их консорциумов способствует как углублению фундаментальных знаний о происходящих процессах в биотопах и входящих в них отдельных клетках, так и удовлетворению практических нужд биотехнологического кластера за счет конструирования новых, на основании полученных знаний о существующих, путях метаболизма, позволяющих получать необходимые человеку продукты. Целью проведенного исследования является определение таксономической принадлежности аборигенного изолята бактерий с оценкой его биотехнологического потенциала.

Так, из реки Везёлка, протекающей по территории города Белгорода, была изолирована аборигенная бактерия, представленная грамотрицательными, образующими сине-фиолетового цвета пигмент, факультативно анаэробными подвижными, каталазоположительными, индолнеобразующими палочками с такими характерными свойствами, как способность расти при $4^{\circ} \mathrm{C}$, проявление лецитиназной активности, образование аммиака, но не Н2S, наличие цитохромоксидазы, отсутствие липолитической активности и образования капсул. Исходя из обнаруженных признаков, определена первичная таксономическая принадлежность выделенного микроорганизма к роду Chromobacterium.

Выделенная бактерия проявляла антагонистические свойства по отношению к таким фитопатогенам, как Alternaria brassicicola F-1864 и Aspergillus unguis F-1754, в чем может заключаться её биотехнологический потенциал в качестве действующего агента средств защиты растений.

Работа поддержана грантом РФФИ-Китай № 20-54-53023. 